https://doi.org/10.5800/GT-2017-8-3-0276

\title{
GEOCHEMICAL CHARACTERISTICS OF ECLOGITES FROM NORTHERN QAIDAM BASIN, CENTRAL CHINA
}

\author{
Xunfei Li, Zhiqiang Wang \\ School of Resources and Environment Engineering, Heifei University of Technology, \\ Anhui 230009, China
}

The occurrence of high-pressure and ultrahigh-pressure eclogites in the northern border of Qaidam basin in central China indicates the existence of a $350 \mathrm{~km}$ orogenic belt. These eclogites provide constraints for reconstructing the tectonic evolution history in this region. In this study, we analyzed nine eclogites sampled from the Xitieshan area, for their major and trace element abundances as well as ${ }^{143} \mathrm{Nd} /{ }^{144} \mathrm{Nd}$ isotopic ratios to investigate the factors controlling geochemical compositions of these eclogites and to infer the tectonic evolution in this region.

The ${ }^{143} \mathrm{Nd} /{ }^{144} \mathrm{Nd}$ ratios of these eclogites vary in the range of $0.512303-0.513588$ indicating derivation from oceanic lithosphere. Dating zircons in these eclogites constrains the metamorphic age to be $\sim 450 \mathrm{Ma}$. After corrected for the metamorphic age, the $\varepsilon N d$ values of the studied eclogites can be divided into two groups. Group 1 samples occur only at the western portion of the studied orogenic belt. They have low LREE/HREE ratios resembling that of N-MORB. However, their $\varepsilon \mathrm{Nd}(450)$ and ${ }^{147} \mathrm{Sm} /{ }^{144} \mathrm{Nd}$ values (9 15 and $0.23-0.28$, respectively) are higher than that of $\mathrm{N}$ MORB (7 9 and $\sim 0.22$, respectively). Furthermore, group 1 samples define a negative correlation between $\varepsilon \mathrm{Nd}(450)$ and ${ }^{147} \mathrm{Sm} /{ }^{144} \mathrm{Nd}$ ratios. The sample with the highest ${ }^{147} \mathrm{Sm} /{ }^{144} \mathrm{Nd}$ value has $\varepsilon \mathrm{Nd}(450)$ approaching the value of MORB. These features can be explained by combination of two processes; first, concentrating garnet by metamorphic differentiation, then, fluid or meltinfiltration to lower the ${ }^{147} \mathrm{Sm} /{ }^{144} \mathrm{Nd}$ ratios resulting in under-correction for the $\varepsilon \mathrm{Nd}(450)$ values.

In contrast, group 2 samples have LREE/HREE higher than group 1 samples, and can be further divided into two subgroups characterized by the absence 
and presence of HFSE depletions, respectively. The geochemical characteristics of the former are similar to those of the E-MORB whereas those of the latter are of typical arc lavas. Those metamorphosed from E-MORB protoliths were collected from the central and eastern parts while eclogites with arc signatures were mainly sampled at the eastern edge of northern Qaidam Basin. Such a systematic spatial distribution possibly indicates two subduction events. The arc protoliths might be resulted from the eastward collision between the
paleo-Qilian ocean and its near-by continent. Then, the subsequent northward subduction of the paleo-Qilian ocean and the associated eastern arcs completely consumed this ocean-arc system leading to the formation of north Qaidam eclogites. Alternatively, the relative proportions of ocean and arc protoliths might reflect the size of the consumed ocean with high proportions of arc-related protoliths corresponding to a smaller ocean. 